\title{
Cystic Fibrosis with Severe Anaemia and Hypoproteinaemia
}

Siddique MA ${ }^{1}$, Khan $\mathrm{K}^{2}$, Bera $\mathrm{A}^{3}$, Ghorai $\mathrm{S}^{4}$, Mallik J5, Sarkar $\mathrm{S}^{6}$

\section{Abstract}

The presentation of cystic fibrosis (CF) is dependent upon which organs are affected. Severe anaemia is reported to occure rarely in patients with CF. We are presenting a case of 2 months old infant admitted with anaemia, malnutrition, hypoproteinaemia and hypoalbuminaemia, without any pulmonary symptoms at the initial presentation. Abnormal sweat chlorides and low faecal elastase level confirmed the diagnosis of CF. Respiratory symptoms and signs developed later on further follow up.

\section{Introduction}

C ystic fibrosis (CF) is an autosomal recessive disorder characterized by impaired chloride transport across the apical membrane of cells as a result of mutations of the CFTR gene ${ }^{1}$. In most patients with CF, pulmonary symptoms initially prevail ${ }^{2}$. Another predominant feature is mal-digestion that frequently begins in early childhood. Pancreatic exocrine dysfunction causes mal-digestion characterised by failure to thrive, diarrhoea, hypoproteinaemia, oedema and anaemia. Severe anaemia as the initial manifestation was described rarely ${ }^{3,4}$. Prospectively, the frequency of clinically significant anaemia has been estimated to develop in $4 \%$ of CF infants ${ }^{5}$.

We describe a male patient with severe anaemia, diarrhoea with oedema and failure to thrive at diagnosis, who developed recurrent respiratory tract infection later.

\section{The Case}

A two month old male infant presented with complaints of frequent passage (40-50 times/day) of dark green stools with oily in consistency. Associated with vomiting, abdominal distension and generalised swelling of whole body for last one and half months. There was no history of fever, cough or breathing difficulty.

He was born at 34 weeks gestation after an uncomplicated pregnancy and weighed $2.1 \mathrm{~kg}$. He was on breast and bottle feed.

Upon clinical examination on admission, the infant was afebrile, drowsy, had dry tongue, tachycardia with low volume pulse, CRT > 3 secs, SpO2: 90\% in room air, BP:64/38 (MAP-44) mmHg. Baby had severe pallor with generalised oedema, weight was $3.5 \mathrm{~kg}(<1 \mathrm{st}$ percentile, $Z$ score -3 ), length was $55 \mathrm{~cm}$ (between $3^{\text {rd }}$ and $50^{\text {th }}$
${ }^{1}$ Dr. Md Abu Bakkar Siddique, MBBS, MD Junior Resident, ${ }^{2} \mathrm{Dr}$. Kalimuddin Khan, MBBS. MD Junior Resident, ${ }^{3}$ Dr. Aparajita Bera, MBBS. MD Junior Resident, ${ }^{4} \mathrm{Dr}$. Sudipta Ghorai, MBBS. MD Senior Resident, ${ }^{5} \mathrm{Dr}$. Jasmine Mallik, MBBS. MD Junior Resident, ${ }^{6}$ Dr. Suman Sarkar, MBBS. MD, Associate Professor. All from the Chittaranjan Seva Sadan College of Obstetrics, Gynaecology and Child Health, Paediatric Medicine, Kalighat, Kolkata, West Bengal, India.

\section{Address for correspondence \\ Dr. Abu Bakkar Siddique \\ E-mail: abu89.cmc@gmail.com}

\section{How to cite}

Siddique MA, Khan K, Bera A, Ghorai S, Mallik J, Sarkar S. Cystic Fibrosis with Severe Anaemia and Hypoproteinaemia. J Nepal Paediatr Soc 2018;38(2):118-121.

doi: http://dx.doi.org/10.3126/jnps.v38i2.19196

This work is licensed under a Creative Commons Attribution 3.0 License. 
percentile. The weight-for-length was $<1^{\text {st }}$ percentile, $Z$ score -3 .

On systemic examination, abdomen was soft and distended with hepatomegaly but no splenomegaly. There was bi-lateral vesicular breath sounds and soft S1, S2, no murmur and no subcostal or intercostal recessions.

Laboratory investigations showed a haemoglobin $4.5 \mathrm{gm} \%$ with a normal mean corpuscular and mean corpuscular haemoglobin concentration and reticulocyte count of $1.5 \%$. The blood smear showed a normochromic normocytic and microcytic hypochromic, anisocytosis, few target cells and tear drop cells seen. The white blood cell count was 9480/cumm with a normal differential count. The number of platelets was normal. Serum electrolytes, renal function tests, serum triglycerides, cholesterol, amylase and lipase were normal. Levels of aspartate aminotransferase (AST) were- $202 \mathrm{U} / \mathrm{L}$, alanine aminotransferase (ALT): 240 $\mathrm{U} / \mathrm{L}$, alkaline phosphatase (ALP): $462 \mathrm{U} / \mathrm{L}$. The total bilirubin level was $0.8 \mathrm{mg} / \mathrm{dL}$ with a direct bilirubin level of $0.3 \mathrm{~g} / \mathrm{dL}$. Total proteins was $3.4 \mathrm{~g} / \mathrm{dL}$, with an albumin of $1.5 \mathrm{~g} / \mathrm{dL}$. Prothrombin (PT) and partial thromboplastin times (PTT) were both normal. Results of serum iron, TIBC were normal but serum ferritin was $518 \mathrm{ng} / \mathrm{ml}$, bone marrow smear, and immunoglobulin panels and anti TG2 IgA antibody were all normal. Parents' $\mathrm{Hb}$ electrophoresis were normal pattern. Blood culture and urine culture were found negative. Stool routine and microscopic results revealed fat droplets in stool. Sudan stain of the stool showed abundant neutral and split fats (>60/HPF) with faecal elastase $<15 \mathrm{mcg} / \mathrm{gm}$ of stool, which is significant, no reducing substance and occult blood in stool. Sweat chloride estimation test was done. It reveals $167.2 \mathrm{mEq} / \mathrm{L}$. The test was repeated after two week, which showed positive result $119 \mathrm{mEq} / \mathrm{L}$. Blood for Common four mutation of CF (Delta F508, G542X, G551D and R553X ) were negative.

The infant was treated with albumin, packed red cells transfusion, antibiotics and pancreatic enzymes(lipase), vitamins A (4000 IU/day), D (400 IU/ day), E (400 u/day) and water soluble vitamins were added. The baby was discharged after four weeks with significant weight gain, normalised blood count and serum albumin with subsidence of oedema.

During next four months, the infant had consistent weight gain. However over that period, baby was admitted in ward several times for respiratory distress.

\section{Discussion}

In view of the multiple manifestations of cystic fibrosis, the following discussion will be limited to a discussion of FTT, anaemia and hypoproteinaemia as it presents in infants with cystic fibrosis.

The symptom complex of hypoproteinaemia, anaemia, and FTT (as seen in our patient), occurs in $5 \%-13 \%$ of patients with cystic fibrosis and is a direct consequence of protein energy malnutrition ${ }^{6,7,8,9}$.

It is frequently misdiagnosed initially as milk protein intolerance, often resulting in formula changes, with further delay in diagnosis and worsening of nutritional status $^{6,810,11}$.

The syndrome has been reported in breast-fed infants more often than those fed cows' milk formula. This symptoms complex occurs most commonly in soy formula-fed infants $6,9,10,11$.

The degree of malnutrition may be underestimated in this group of infants as a result of oedema secondary to hypoproteinaemia. Oedema within the first three months may be sufficiently severe to produce shock ${ }^{12}$.

The precise aetiology of hypoproteinaemia is yet to be established. Hypoproteinaemia is also seen in patients with CF as results of extensive hepatic disease with secondary liver synthetic dysfunction and in patients with severe chronic pulmonary disease, cor pulmonale and increased plasma volume ${ }^{13}$. It may be that the milk intake is insufficient to compensate for the protein loss due to malabsorption. It has been established that there is no leakage of protein into the gut. Liver dysfunction is unlikely to be the cause as liver function tests and biopsy may be normal' and, if abnormal, there is a rapid reversion to normality with a change in diet and correction of the hypoproteinaemia ${ }^{3,6}$.

The cause of anaemia in this syndrome is also not clear. The anaemia showed mixed type of picture, normochromic normocytic, microcytic hypochromic with anisocytosis. Most previous studies describe the anaemia as haemolytic, implicating the malabsorption of fat-soluble vitamin $E^{5,14,15,16,17,18,19}$, which appears to act as a protective antioxidant toward peroxidation of membranous polyunsaturated fatty acids ${ }^{20}$. It has also been shown, however, that vitamin $\mathrm{E}$ deficiency in CF patients is irrespective of pancreatic function, body weight, and even the administration of pancreatic enzymes and lipid soluble vitamins ${ }^{21}$. Among infants newly diagnosed with $C F$, the frequency of vitamin $E$ deficiency has been found to be very high, ranging from 38 to $59 \%^{22,13}$. Interestingly, only approximately $4 \%$ of these children develop clinically significant anaemia ${ }^{4,5}$, suggesting that additional modifying factors most likely contribute to the manifestation of severe anaemia in CF 
patients. Although in our patient, the only intimation of haemolysis was mild reticulocytosis and other features did not contribute to typical haemolytic anaemia, due to lack of the data we could not rule out the importance of vitamin $\mathrm{E}$ deficiency in the initiation of anaemia. Although after the diagnosis of CF, vitamin E was supplemented in low levels according to present guidelines, signs of haemolytic anaemia did not reoccur. The hyperchromic macrocytosis detected is harder to explain. One reason could be a deficiency of folic acid due to malabsorption, or increased folate utilisation by rapidly-proliferating bone marrow in chronic haemolytic anaemia, or a combination of both. Although anaemia in our patient was not prolonged, persistent malnutrition plausibly

\section{References}

1. Quinzii C, Castellani C. The cystic fibrosis transmembrane regulator gene and male infertility. $J$ Endocrinol Invest 2000;23(10):684-9.

2. Rosenstein BJ, Cutting GR. The diagnosis of cystic fibrosis: a consensus statement. Cystic fibrosis foundation consensus panel. J Pediatr 1998;132(4):589-95.

3. Dolan TE. Haemolytic anemia and edema as the initial signs in infants with cystic fibrosis. ClinPediatr 1976;59:533-42.

4. Sinaasappel M, Stern M, Littlewood J, Wolfe S, Steinkamp G, Heijerman HGM, et al. Nutrition in patients with cystic fibrosis: a European consensus. $J$ Cystic Fibrosis 2002;1:51 -75.

5. Wilfond BS, Farrell PM, Laxova A. Severe haemolytic anemia associated with vitamine $E$ deficiency in infants with cystic fibrosis. ClinPediatr 1994;33:2-7.

6. Lee PA, Roloff DW, Howatt WF. Hypoproteinemia and anemia in infants with cystic fibrosis: a presenting symptom complex often misdiagnosed. JAMA 1974;228:585-88.

7. Nielsen $\mathrm{OH}$, Larsen BF. The incidence of anemia, hypoproteinemia, and edemain infants as presenting symptoms of cystic fibrosis: a retrospective survey of the frequency of this symptom complex in 130 patients with cystic fibrosis. J PediatrGastroenterolNutr 1982;1:355-359.

8. Abman SH, Accurso FJ, Bowman CM. Persistent morbidity and mortality of protein calorie malnutrition in young infants with CF. J PediatrGastroenterolNutr 1986;5:393-96.

9. Skopnik H, Heimann G. Manifestation einerKuhmilchproteinintoleranzbeiMukoviszidosemit der symptomtrias-Hyporoteinamie, Odeme und Anamie. KlinPadiatr 1987;199:453-56. contributed to the manifestation of anaemia. Shahidi et al. ${ }^{10}$ attributed the anaemia to protein deficiency which led to a reduced iron binding capacity and, in turn, to a low serum iron concentration.

\section{Conclusion}

The spectrum of presentation of CF is wide and varied. CF can presents with severe anaemia and hypoproteinaemia. In rare cases of CF, anaemia may be the leading symptom present together with malnutrition. More investigations are needed to clarify the mechanisms of early anaemia in CF and to assess the possible prognostic value of clinically significant anaemia in CF babies.

10. Shahidi NT, Diamond LK, Shwachman H. Anemia associated with protein deficiency. $J$ Pediatr 1961;59:533-42.

11. Fleisher DS, DiGeorge AM, Barness LA, Cornfeld D. Hypoproteinemia and edema in infants with cystic fibrosis of the pancreas. J Pediatr 1964;64:341-48.

12. Bass HN, Miller AA. Cystic fibrosis presenting with anemia and hypoptoeinemia in identical twins. Pediatrics 1977;59:126-27.

13. Strober W, Peter G, Schwartz RH. Albumin metabolism in cystic fibrosis. Pediatrics 1969;43:416-426.

14. Kere J, Estivill X, Chillon M, Morral N, Nunes V, Norio R, et al. Cystic fibrosis in a low-incidence population: two major mutations in Finland. Hum Genet 1994;93:1626.

15. Estivill X, Bancells C, Ramos C, Biomed CF. Mutation analysis consortium. Geographic distribution and regional origin of 272 cystic fibrosis mutations in European populations. Hum Mutat 1997;10:135-54.

16. Strandvik B, Bjorck E, Fallstrom M, Gronowitz E, Thountzour- is J, Lindblad A, et al. Spectrum of mutations in the CFTR gene of patients with classical and atypical forms of cystic fibrosis from southwestern Sweden: identification of 12 novel mutations. Genet Test2001;5:235-42.

17. Teder M, Klaassen T, Oitmaa E, Kaasik K, Metspalu A. Distribution of CFTR gene mutations in cystic fibrosis patients from Estonia. J Med Genet 2000;37(8):16.

18. Farrell PM, Bieri JG, Fratantoni JF, Wood RE, di Sant'Agnese PA. The occurrence and effects of human vitamin E deficiency. A study in patients with cystic fibrosis. J Clin Invest 1977;60:233-41.

19. Swann IL, Kendra JR. Anaemia, vitamin E deficiency and failure to thrive in an infant. ClinLab Haematol 1998;20(1):61-3.

20. Winklhofer-Roob BM, Ziouzenkova O, Puhl H, Ellemunter H, Greiner P, Muller G, et al. Impaired resistance to oxidation of low density lipoprotein 
in cystic fibrosis: improvement during vitamin $\mathrm{E}$ supplementation. Free RadicBiol Med 1995;19:72533.

21. Lancellotti L, D’Orazio C, Mastella G, Mazzi G, Lippi $U$. Deficiency of vitamins $E$ and $A$ in cystic fibrosis is independent of pancreatic function and current enzyme and vitamin supplementation. Eur $J$ Pediatr 1996;155(4):281-5
22. Sokol RJ, Reardon MC, Accurso FJ, Stall C, Narkewicz $\mathrm{M}, \mathrm{Abman} \mathrm{SH}$, et al. Fat-soluble-vitamin status during the first year of life in infants with cystic fibrosis identified by screening of newborns. Am J ClinNutr 1989;50:1064 -71.

23. Marcus MS, Sondel SA, Farrell PM, Laxova A, Carey $P M$, Langhough $R$, et al. Nutritional status of infants with cystic fibrosis associated with early diagnosis and intervention. Am J ClinNutr 1991;54:578 -85. 